\title{
«Les inscriptions de Baybars dans le Bilād al-Șām. Une expression de la légitimité du pouvoir ».Studia Islamica, vol. 97, 2003 [paru en 2006], pp. 57-85.
}

\section{Ludvik Kalus}

\section{(2) OpenEdition}

1 Journals

\section{Édition électronique}

URL : http://journals.openedition.org/abstractairanica/27422

DOI : 10.4000/abstractairanica. 27422

ISSN : 1961-960X

Éditeur :

CNRS (UMR 7528 Mondes iraniens et indiens), Éditions de l'IFRI

\section{Édition imprimée}

Date de publication : 15 mai 2008

ISSN : 0240-8910

\section{Référence électronique}

Ludvik Kalus, « « Les inscriptions de Baybars dans le Bilād al-Șām. Une expression de la légitimité du pouvoir ». Studia Islamica, vol. 97, 2003 [paru en 2006], pp. 57-85. », Abstracta Iranica [En ligne], Volume 29 | 2008, document 144, mis en ligne le 15 septembre 2008, consulté le 26 septembre 2020. URL : http://journals.openedition.org/abstractairanica/27422 ; DOI : https://doi.org/10.4000/ abstractairanica.27422

Ce document a été généré automatiquement le 26 septembre 2020

Tous droits réservés 
«Les inscriptions de Baybars dans le Bilād al-ṣām. Une expression de la légitimité du pouvoir ». Studia Islamica, vol. 97, 2003 [paru en 2006], pp. 57-85.

Ludvik Kalus 
Le sultan Baybars (658-676/1260-1277), réel fondateur du pouvoir mamelouk en Égypte et en Syrie, issu comme tous les mamelouks de condition servile, s'est hissé à la tête du monde musulman de son temps pour devenir un héros légendaire. Lui-même a soigneusement forgé sa légitimité en instaurant au Caire un nouveau khalifat abbaside et en s'attribuant des qualités dignes des grands souverains musulmans (et même non musulmans) du passé.

2 D.A. s'est proposé d'observer son ascension et les moyens qu'il a mis en œuvre à travers une analyse minutieuse de sa titulature, telle qu'elle apparait dans les inscriptions arabes de Syrie de son époque. Elle a pu ainsi dégager l'image que ce souverain voulait répandre, dans un environnement hostile où étaient encore présents les Croisés et les Mongols. Ainsi nous livre-elle, toujours en partant de la titulature, les différentes facettes de Baybars, présentées dans les sections suivantes : "Baybars, souverain musulman idéal »; « Baybars, restaurateur du califat et protecteur des lieux saints »; « La mise en œuvre de la symbolique coranique "; "Victoires militaires et nouvelle topographie religieuse »; « Baybars 'nouvel Alexandre' ou 'dernier empereur' ». La liste des titres de Baybars relevés dans les principales inscriptions à son nom, point de départ de cette étude et présentée en annexe, constitue une base précise qui est exploitée avec beaucoup de perspicacité. Le résultat en est un article agréable à lire qui nous donne une excellente présentation de l'entrée dans l'histoire de ce grand souverain musulman devenu légendaire.

INDEX

Thèmes : 4.1. Histoire médiévale

\section{AUTEURS}

LUDVIK KALUS

EPHE - Paris 